\title{
TERRITORIALIZAÇÃO DO CAPITAL ESTRANGEIRO NO SETOR SUCROENERGÉTICO DE MINAS GERAIS
}

\section{TERRITORIALIZATION OF FOREIGN CAPITAL IN THE SUGAR-ENERGY SECTOR OF MINAS GERAIS}

\author{
Natália Lorena Campos \\ Doutora em Geografia, Universidade Federal de Uberlândia, MG, Brasil \\ Bolsista PNPD/CAPES \\ natalia.campos@ufu.br \\ João Cleps Junior \\ Professor do Instituto de Geografia e do Programa de Pós-Graduação em Geografia, Universidade Federal \\ de Uberlândia, MG, Brasil \\ Bolsista Produtividade em Pesquisa/CNPq \\ jcleps@ufu.br
}

\section{Resumo}

Desde meados da década de 1990 o setor sucroenergético brasileiro tem se aliado ao capital externo e a empresas estrangeiras interessadas na produção de commodities agrícolas. Minas Gerais insere-se nesse movimento na década de 2000, marcada por constantes processos de fusões e/ou aquisições, em que empresas mundiais uniram-se às agroindústrias canavieiras, num período de maior abertura econômica do setor pós crise financeira de 2008. Nesse sentido, o objetivo deste artigo é compreender como esta dinâmica atual do setor ocorreu no estado, analisando a territorialização do capital externo e o processo de internacionalização das agroindústrias canavieiras, estas concentradas na mesorregião Triângulo Mineiro/Alto Paranaíba. Metodologicamente, foi levantado o número de empreendimentos no estado com participação de capital estrangeiro, assim como referencial teórico relacionado à temática e análise de dados de produção, número de usinas, preço da terra, entre outros. O presente trabalho é resultado de pesquisas voltadas para a compreensão do uso corporativo do território, através da apropriação capitalista e compra de terras pelas empresas transnacionais para a produção de commodities agrícolas, sobretudo da cana-de-açúcar e etanol. $\mathrm{O}$ processo de internacionalização decorrente segue a dinâmica da financeirização da riqueza e compreende, inclusive, a captura dos recursos naturais, da biodiversidade atingindo os demais componentes do espaço agrário como principalmente o emprego rural.

Palavras-chave: Internacionalização. Crise Financeira. Setor sucroenergético. Fusões/aquisições. Minas Gerais.

\begin{abstract}
Since the mid-1990s, the Brazilian sugar-energy sector has been allied with foreign capital and foreign companies interested in the production of agricultural commodities. Minas Gerais was part of this movement in the 2000s, marked by constant mergers and/
\end{abstract}


or acquisitions, in which global companies joined sugar cane agro-industries, in a period of greater economic opening in the sector after the 2008 financial crisis.

In this sense, the objective of this article is to understand how this current sector dynamics occurred in the state, analyzing the territorialization of foreign capital and the internationalization process of sugarcane agro-industries, which are concentrated in the Triângulo Mineiro / Alto Paranaíba mesoregion. Methodologically, the number of enterprises in the state with participation of foreign capital was raised, as well as theoretical framework related to the theme and analysis of production data, number of units, land price, among others. The present work is the result of researches aimed at understanding the corporate use of the territory, through the capitalist appropriation and purchase of land by transnational companies for the agricultural commodities production, with emphasis on sugar cane and ethanol. The resulting internationalization process follows the dynamics of the financialization of wealth and includes, even, the capture of natural resources and the biodiversity, reaching the other agrarian space components, in special, the rural employment.

Keywords: Internationalization. Financial crisis. Sugar-energy sector, Mergers/acquisitions. Minas Gerais.

\section{Introdução}

A agricultura brasileira sofreu intensas transformações ao longo dos anos, sobretudo em seu processo de financeirização, envolvendo o Estado via financiamento público pelo BNDES e, mais recentemente, com um sistema de financiamento privado baseado nas tradings internacionais. Com maior intensidade na década de 1990, novos sujeitos surgiram no cenário agrícola na figura de empresas mundiais que passaram a controlar diversos segmentos agrícolas, marcada por uma "mudança profunda com a ampliação da influência do capital monopolista internacional na economia brasileira" (MEDEIROS, 2015, p. 6223).

O agronegócio canavieiro insere-se nessa dinâmica durante este período, mas é a partir do início do século XXI que intensifica-se, marcado por constantes processos de fusões e/ou aquisições, em que empresas mundiais uniram-se às agroindústrias canavieiras num período de maior abertura econômica do setor pós crise financeira de 2008.

O estado de Minas Gerais tem se tornado um importante espaço para a reprodução do setor sucroenergético brasileiro e de capitais transnacionais, e o processo de globalização foi determinante para a entrada desses capitais. Com início durante a modernização da agricultura e com as políticas voltadas à expansão da fronteira agrícola para as áreas de Cerrado nas décadas de 1970 e 1980, o agronegócio ganhou força na região, inicialmente com a cultura da soja e a partir dos anos 90 com a cana-de-açúcar. 
O Triângulo Mineiro/Alto Paranaíba ${ }^{1}$ é uma importante mesorregião geográfica produtora de cana-de-açúcar, o que delimitará nossa análise em diversos momentos. Ele concentra atualmente [2019] 60\% das usinas do estado de Minas Gerais, essas comandadas por grupos da região Nordeste, Centro-Sul e mais recentemente por grupos estrangeiros. A entrada do capital externo no setor sucroenergético de Minas Gerais ocorreu durante o início da década de 2000, período marcado por processos de fusões e aquisições de empresas brasileiras e multinacionais que associam o território brasileiro à produção de agrocombustíveis, e intensificou-se logo após a crise financeira de 2008. O momento da crise facilitou a entrada do capital externo com o auxílio do Estado em incentivos de financeirização do setor.

Minas Gerais possui 7 usinas totalmente controladas por capital estrangeiro (conforme mapa 1), sendo basicamente os grupo Bunge (Estados Unidos/Holanda), British Petroleum (Reino Unido), Dow-chemical (Estados Unidos) Louis Dreyfus Company (França) e Adecoagro (Argentina); e duas usinas com associação de capitais: a primeira representada pela Petrobrás (Brasil) e Total (França), e a segunda pela Companhia Mineira de Açúcar e Álcool - CMAA (Brasil) e Indofood Agri (Indonésia). Recentemente, em 2019, foi anunciada a fusão do grupo Bunge, que possui três usinas no estado, com o grupo British Petroleum.

Assim, o objetivo deste trabalho é discutir o processo de internacionalização do setor sucroenergético mineiro a partir da interação de capitais (interno e externo), com maior ênfase para a mesorregião Triângulo Mineiro/Alto Paranaíba, destacando os grupos estrangeiros que se territorializam, bem como os efeitos da internacionalização nas esferas políticas, econômicas e sociais.

A partir de referencial teórico selecionado nas temáticas do agronegócio e do território, sobretudo quanto ao seu uso, a internacionalização do setor sucroenergético com reflexos no mercado de terras. A coleta de dados foi realizada em órgãos oficiais e entidades representativas do setor, como União da Indústria de Cana-de-açúcar - UNICA, União dos Produtores de Bioenergia - UDOP e o Ministério da Agricultura, Pecuária e Abastecimento - MAPA; além de sites próprios das unidades canavieiras do estado e informações diretas obtidas com representantes do setor sucroenergético de Minas Gerais, como o Sindicato da Indústria de Fabricação do Álcool no Estado de Minas Gerais SIAMIG. 
Mapa 1: Minas Gerais - Relação das usinas de capital nacional e estrangeiro em operação (2019)

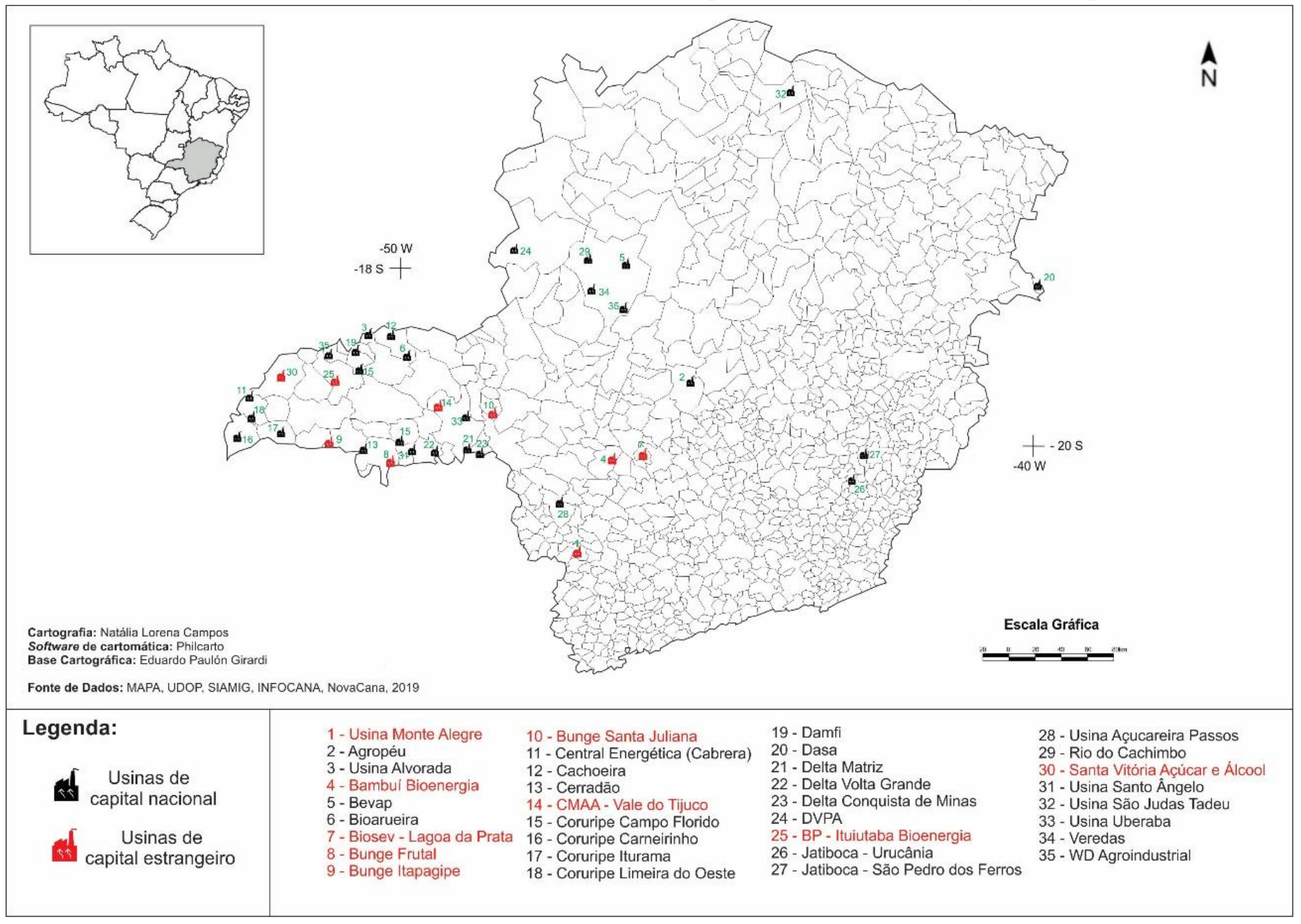

Fonte: Ministério da Agricultura, Pecuária e Abastecimento (MAPA), União dos Produtores de Bioenergia (UDOP) e Portal NovaCana, 2019. Org.: CAMPOS, N.L., 2019. 
Buscamos, portanto, compreender a dinâmica atual do setor sucroenergético em Minas Gerais, cada vez mais internacionalizado, com a apropriação de territórios por grupos estrangeiros e sua relação com a concentração de terras na região. Outra preocupação do estudo foram os impactos do avanço da cana-de-açúcar na agropecuária, trazendo efeitos negativos aos pequenos produtores familiares, assentados e camponeses, que pressionados, muitas vezes são cooptados pela agricultura globalizada, cedendo suas terras para a produção de monocultivos.

\section{A internacionalização do setor sucroenergético brasileiro e a crise financeira de 2008}

Não somente no agronegócio canavieiro, mas em toda cadeia agrícola, a agricultura encontra-se mundializada e esse processo, segundo Oliveira (2016), corresponde ao novo período histórico do desenvolvimento do capitalismo, marcado pela presença das empresas mundiais.

[...] a necessidade de movimentos mundiais de capitais, a produção capitalista mundial e a existência de ações de governos em nível mundial articulados contraditoriamente, estão na raiz da formação do capitalismo monopolista mundializado. Portanto, foi a partir desse processo, que os Estados nacionais permitiram que as empresas monopolistas mundiais passassem a se constituir nas novas organizações de controle da economia capitalista mundial. (OLIVEIRA, 2016, p. 97).

As transformações capitalistas no campo brasileiro unificaram o capital industrial ao capital financeiro, o proprietário de terras e o capitalista da agricultura em uma só figura, empresa ou nome. Como exemplo disso, temos a fusão da produção de cana-deaçúcar com as usinas de açúcar ou destilarias de álcool, nas quais a industrialização e a agricultura são etapas de um mesmo processo. Diante a desregulamentação do setor sucroenergético na década de 1980, onde a intervenção estatal era dominante e os subsídios às usinas foram cortados, o setor precisou se reestruturar e buscar novos investimentos. O ano de 1995 marcou o início da desregulamentação do mercado brasileiro de açúcar e álcool. Foi após esse período, num processo marcado por fusões e aquisições de empresas, que teve início os investimentos estrangeiros na atividade canavieira no Brasil.

Esta tendência ocorreu a partir dos anos 2000, período em que o país estava passando por uma profunda e acelerada internacionalização de seus ativos e da produção (BENETTI, 2008). Existia uma grande expectativa do Brasil protagonizar uma redefinição da matriz energética global através da produção de biocombustíveis a partir da cana-de- 
açúcar. Segundo a autora, um primeiro fator a induzir a busca por novas fontes de energia foi o movimento dos preços internacionais do petróleo, e outro fator está na insegurança dos maiores países consumidores de petróleo quanto às condições de abastecimento de seus mercados (BENETTI, 2008). Existia uma preocupação com a segurança energética nos Estados Unidos, na União Europeia, no Brasil, na China e na Índia.

Em Minas Gerais, esse processo teve maior intensificação a partir da crise financeira de 2008, momento em que se acentua o processo de internacionalização de capitais nas agroindústrias canavieiras.

A crise financeira global de 2008-2009 reduziu abruptamente o crédito e muitas fábricas do setor canavieiro chegaram a níveis insustentáveis de inadimplência. Investimentos em novas usinas foram suspensos e o investimento, primariamente estrangeiro, foi usado para comprar empresas em dificuldade ou caminhando para a falência. (WILKINSON, 2015, p. 04).

A entrada de novas empresas no setor foi facilitada pela crise mundial deflagrada em 2008, cujas consequências desestruturaram sua organização e impactaram diretamente a gestão e operação das usinas. As dificuldades estão relacionadas, principalmente, a:

[...] escassez de financiamento; elevado custo financeiro para investimentos; perdas cambiais e elevado endividamento de algumas usinas, principalmente daquelas que apostaram na grande demanda de etanol prevista em anos anteriores; e a diminuição das exportações de etanol em função da retração da demanda externa. (VENCOVSKY, 2013, p. 52 apud GOES; MARRA, 2009; e CASTRO; DANTAS, 2009).

Ainda, com a descoberta do pré-sal - novas reservas de petróleo em águas territoriais brasileiras, coincidiu com a crise mundial e contribuiu ainda mais para relegar a estratégia do biocombustível etanol a um segundo plano. Como saída, o setor buscou se reestruturar financeira e societariamente. As transformações ocorridas no setor sucroenergético a partir dos anos 2000, configurou-se, segundo Oliveira (2016), na formação de grupos empresariais monopolistas que passaram a controlar o agronegócio canavieiro, associando-se a empresas nacionais.

O papel do capital financeiro e das empresas multinacionais ajudou o setor a enfrentar a crise. A fusão do Grupo Cosan com a Shell, formando a empresa Raízen em 2008 é um exemplo da captação de recursos do mercado financeiro. Ela foi a primeira empresa do agronegócio brasileiro a abrir seu capital em Bolsa de Valores em 2005.

Outras empresas também ingressaram no setor sucroenergético no contexto da internacionalização como, por exemplo, os grupos British Petroleum (BP), Archer Daniels Midland (ADM) e Bunge. Segundo o Relatório de Direitos Humanos (2012) 
elaborado pela Rede Social de Justiça e Direitos Humanos, a crescente participação dessas empresas multinacionais no setor gera maior concentração de capitais e, aparentemente, está relacionada com a busca por investimentos tidos como "flexíveis", considerando-se uma suposta estabilidade no mercado de terras no Brasil. Assim, o movimento de concentração de capitais decorre da própria crise econômica mundial.

Houve uma reorganização do setor que buscou no planejamento estratégico setorial uma visão de longo prazo que determinasse as competências essenciais merecedoras de investimentos. Algumas medidas foram criadas pelo Estado a fim de superar a crise financeira, como a "fusão de grupos empresariais, visando à capitalização e o escalonamento das dívidas num horizonte de longo prazo, que já está acontecendo entre grupos nacionais e estrangeiros" (GOES; MARRA, 2009, p. 4). O momento de crise enfrentado pelo setor sucroenergético fez com que despertasse a atenção de investidores externos que estão altamente interessados e apostando na expansão internacional do etanol e que o setor sucroenergético vive um momento atípico.

Macêdo (2011) indica que houve dois ciclos de fusão e aquisição (F\&A) na agroindústria canavieira. O primeiro (1999 a 2001) ocorreu após a fase de retração do setor devido a desregulamentação em 1999 e descapitalização de diversas usinas. Os grupos melhor estruturados compraram as usinas que se encontravam mais endividadas e sem condições de continuar atuando no setor e de expandir a produção. O segundo ciclo teve início em 2007, em que algumas empresas conseguiram enfrentar a crise econômica adotando estratégias de fusões e aquisições. Foi no auge do segundo ciclo que se observou um grande interesse de grupos internacionais no setor sucroenergético brasileiro. Com a abertura do capital para novos investimentos, outros grupos, sobretudo estrangeiros passaram a investir no setor sucroenergético brasileiro, tornando-se acionistas das empresas brasileiras, uma lógica do capital financeiro portador de juros.

\footnotetext{
A crise de 2008 potencializou esse movimento em razão da escassez de crédito e endividamento de grupos nacionais, favorecendo dessa forma a estratégia de adquirir usinas já estabelecidas (brownfields) em detrimento da instalação de novas unidades de produção (greenfields). Naquele momento, ficou mais atrativo investir na aquisição de grupos endividados do que ampliar a capacidade de produção pela construção de novas usinas. (MACÊDO, 2011, p. 43).
}

Os dois ciclos tiveram fases distintas, no qual o segundo demonstrou a participação do capital externo. Segundo dados da KPMG ${ }^{2}$ (2008), 88 transações de F\&A 
ocorreram no Brasil entre 1995 a 2007, sendo 59 no estado de São Paulo, 6 em Minas Gerais, 5 no Mato Grosso do Sul e 3 em Goiás.

Diante das crises ocorridas no setor na década de 2000, identificamos três fases recentes da expansão canavieira que criaram um ambiente favorável à consolidação do setor sucroenergético. A primeira fase, com início no final de 2006, foi a das aquisições e fusões entre grupos tradicionais do setor sucroalcooleiro. A segunda onda foi observada com as tradings companies investindo em grupos que sofreram com a crise de liquidez de 2008. Nessa fase, foi verificada a mudança de estratégia de algumas empresas, redirecionando capital para a produção de açúcar e etanol em detrimento de outras operações consideradas tradicionais. A terceira fase, no período atual, é a das empresas de energia investindo em unidades produtoras de etanol e energia elétrica. Certamente, esse movimento vai alterar fortemente a atual estrutura da indústria (CLEPS JUNIOR, 2015).

Alguns fatores concorrem para este processo de internacionalização do capital. Entre eles, a redução de crédito para o setor fez com que ocorressem fusões e a internacionalização do setor a fim de suprir o aumento na demanda doméstica pelo etanol. Neste processo, "a atuação dos fundos de investimento no setor ocorre tanto através da aquisição completa de usinas quanto da associação ou fusão" (XAVIER; PITTA; MENDONÇA, 2012, p. 38). Além das fusões entre empresas nacionais, empresas de capital estrangeiro estão investindo cada vez mais no setor sucroenergético brasileiro, concomitantemente na aquisição de terras. Segundo Pinheiro (2015), com a extinção do IAA, a liberação da produção, distribuição e revenda do açúcar abriu espaço para a entrada de empresas estrangeiras interessadas na exportação do produto. Além disso, os estímulos à produção de etanol e a criação da tecnologia flexfuel também estimularam a entrada do capital estrangeiro no setor.

O movimento da internacionalização iniciou por volta dos anos 2000 com alguns grupos que já atuavam no país em outros setores agrícolas, “muitos deles atuando em parceria com empresas tradicionais (aproveitando-se do know-how destas no ramo sucroenergético)" (PINHEIRO, 2015, p. 111).

O grupo Louis Dreyfus Company - LDC (França) foi o primeiro a adentrar no setor com a aquisição, entre 2000 e 2004, de usinas no estado de São Paulo e Minas Gerais. O grupo atua no Brasil desde 1946 nas atividades de processamento de oleaginosas, de citros e mais recentemente na produção de açúcar, álcool e energia. Através da LDC Bioenergia 
S.A, atua na produção de cana-de-açúcar, na industrialização, no comércio e na exportação de açúcar, álcool e seus derivados, bem como na cogeração de energia. (DOMINGUES, 2010, p. 49). Sua primeira usina foi adquirida no município de Leme (SP) em 2000. Daí em diante, foi aumentando e incrementando o setor canavieiro e atualmente conta com 13 usinas no país, nos estados de São Paulo (7), Minas Gerais (1), Mato Grosso do Sul (3), Rio Grande do Norte (1) e Paraíba (1).

O período foi marcado por um processo de concentração e centralização de capitais com a presença do capital externo e as multinacionais. A associação com empresas brasileiras foi a primeira forma de atuação, pois estas já tinham o know-how da atividade. As primeiras empresas a entrarem foram as tradings companies, "algumas das quais já atuavam no Brasil em outros setores agrícolas ou mesmo na comercialização do açúcar” (PINHEIRO, 2015, p. 111).

\begin{abstract}
Além das tradings, algumas cooperativas agrícolas francesas também aportaram no país, interessadas no aumento da demanda do açúcar no mercado internacional. [...] essas empresas não ficaram apenas na compra e venda do açúcar: algumas delas começaram a adquirir as usinas (e com elas seus ativos, tais como as terras próprias, armazéns entre outros), associaram-se a grupos nacionais ou mesmo investiram em novos projetos, que no jargão de mercado denominam-se greenfields. (PINHEIRO, 2015, p. 111).
\end{abstract}

Assim, houve a entrada das tradings como a LDC (França), Cargill (EUA), ADM (EUA), Bunge (Holanda/EUA), Mitsui (Japão) entre outros; dos fundos de investimentos com a CNAA (Brasil/EUA), Brenco (EUA/Brasil), Infinity Bio-Energy (Reino Unido) etc; da produção agrícola com a Shree Renuka (Índia), Adecoagro (Argentina), Tereos (França), etc; de petroleiras e químicas temos a British Petroleum (Inglaterra), Shell (Holanda) e Brasken (EUA); em biotecnologia a Amyris (EUA) e em energia elétrica a Abengoa (Espanha). Neste processo, atuaram no estado de Minas Gerais grupos como Louise Dreyfus, Cargill, CNAA, British Petroleum, ADM, Adecoagro, Infinity Bio-energy, Bunge, Mitsui, Dow-chemical, Total e IndoAgri.

Conjuntamente com a internacionalização, o período posterior aos anos 2000 foi o que mais captou recursos do BNDES para o setor sucroenergético. Entre 2000 e 2013 foram investidos mais de R\$ 50 bilhões, dos quais grande parte destinou-se à expansão e modernização da capacidade produtiva já instalada e implantação de novas unidades industriais; e uma parcela foi destinada à etapa agrícola para a aquisição de terras, formação de novos canaviais e renovação dos já existentes (PINHEIRO, 2015). O autor ainda ressalta que os investimentos realizados pelo BNDES também colaboraram com a oligopolização 
e internacionalização do setor ocorridos a partir de 2000, "já que as grandes empresas foram as que mais tomaram os empréstimos" (PINHEIRO, 2015, p. 113).

Conforme PITTA et. al (2014), as corporações estrangeiras que têm se inserido no segmento canavieiro adotam como principal estratégia a busca pela ampliação de sua presença em regiões identificadas como novas áreas para a expansão do monocultivo de cana. Elas têm se concentrado na região Sul do estado de Goiás, Leste do Mato Grosso do Sul, Noroeste Paulista e Triângulo Mineiro, regiões em que as características físicas e ambientais são extremamente favoráveis ao cultivo da cana.

No item seguinte, iremos aprofundar nossa discussão no estado de Minas Gerais, apontando os agentes envolvidos no processo de internacionalização do setor sucroenergético.

\section{Os investimentos estrangeiros em Minas Gerais}

A participação do capital estrangeiro no setor sucroenergético de Minas Gerais cresceu a partir de meados da primeira década do século XXI, no comando ou com participação acionária nas empresas do setor. A entrada das grandes corporações multinacionais e grupos financeiros internacionais substituiu gradativamente a administração familiar de usinas tradicionais. Conforme Siqueira e Castro Junior (2010), esse processo é caracterizado pelo aumento da presença de grandes grupos locais, como Grupo José Pessoa, Cosan e Carlos Lyra, e pela entrada de grandes grupos internacionais no mercado local, como Louis Dreyfus Commodities (LDC) e Tereos. "A concentração das compras tem ocorrido na região Sudeste, principalmente aos custos mais baixos de produção" (SIQUEIRA; CASTRO JUNIOR, 2010, p. 711).

Os autores comentam que houve uma reestruturação da agroindústria canavieira, esta, inserida em um processo mais amplo de intenso movimento de concentração e centralização de capitais na agroindústria nacional, devido ao aumento das falências ocasionadas pela crise financeira mundial, das fusões e aquisições e com a instalação de novas usinas de grupos econômicos tradicionais, ou seja, além da internacionalização como forma de capitalização dos investimentos das multinacionais, os grupos tradicionais do setor também buscaram se estabelecer nas regiões em que a produção canavieira estava consolidada (por exemplo, o estado de São Paulo) e em regiões em expansão (sobretudo Goiás e Minas Gerais). Isso revela dois fenômenos: de concentração e centralização de 
capitais e transferência de capitais do setor de uma região para outra, com a instalação de novas unidades produtivas.

A internacionalização do setor no estado teve início em 2001 e desde então diversas modificações ocorreram nesse cenário. Alguns grupos entraram no setor, porém, não se mantiveram, enquanto outros permanecem até o presente momento. A figura 1 retrata a movimentação estrangeira no estado desde 2011 até 2019 quando foi registrada a última ocorrência relacionada à internacionalização.

O primeiro grupo a aparecer no cenário mineiro foi o francês Louis Dreyfus Company - LDC ao adquirir uma unidade no município de Lagoa da Prata (mesorregião Central Mineira), passando a chamar Biosev-LDC. O Biosev-LDC é um dos grupos com maior representatividade no país, possuindo dez unidades agroindustriais em operação nos estados de São Paulo, Mato Grosso do Sul, Paraíba, Rio Grande do Norte e a unidade em Minas Gerais, além de um terminal próprio no porto de Santos (SP). Sua origem no país remonta a 2000, quando o Grupo LDC adquiriu a usina em Leme (SP). Posteriormente foram incorporadas outras usinas ao grupo e em 2009 surgiu a LDC-SEV - que futuramente tornaria Biosev, a partir da fusão da LDC Bioenergia com a Santelisa Vale. O grupo atua no mercado global de commodities e comercializa seus produtos no Brasil e em países da América do Norte, Europa, África, Ásia, Oriente Médio e Oceania. Em 2013 a empresa abriu o capital e desde então suas ações são negociadas no Segmento Novo Mercado da B3 (Bolsa Balcão Brasil) (LDC, 2018).

Em 2006, a Adecoagro, grupo de origem argentina com fundo formado por várias empresas e coordenado por George Soros, comprou a Usina Monte Alegre, no município de Monte Belo (mesorregião Sul/Sudoeste de Minas) marcando sua inserção no setor sucroenergético brasileiro. O grupo ainda consolidou sua expansão para os demais países latino-americanos com a abertura de capital na Bolsa de Valores de Nova York em 2011. Segundo Almeida e Guida (2017, p. 159), além de atuar na produção agrícola e agroindustrial, o foco principal da empresa "está fortemente vinculado ao mercado imobiliário rural, por meio da aquisição e valorização em médio prazo (em torno de sete anos) dos preços das terras", ocasionando debates em relação ao processo de land grabbing - estrangeirização/controle de terras. 
Figura 1: Evolução da internacionalização do setor sucroenergético em Minas Gerais (2011-2019)

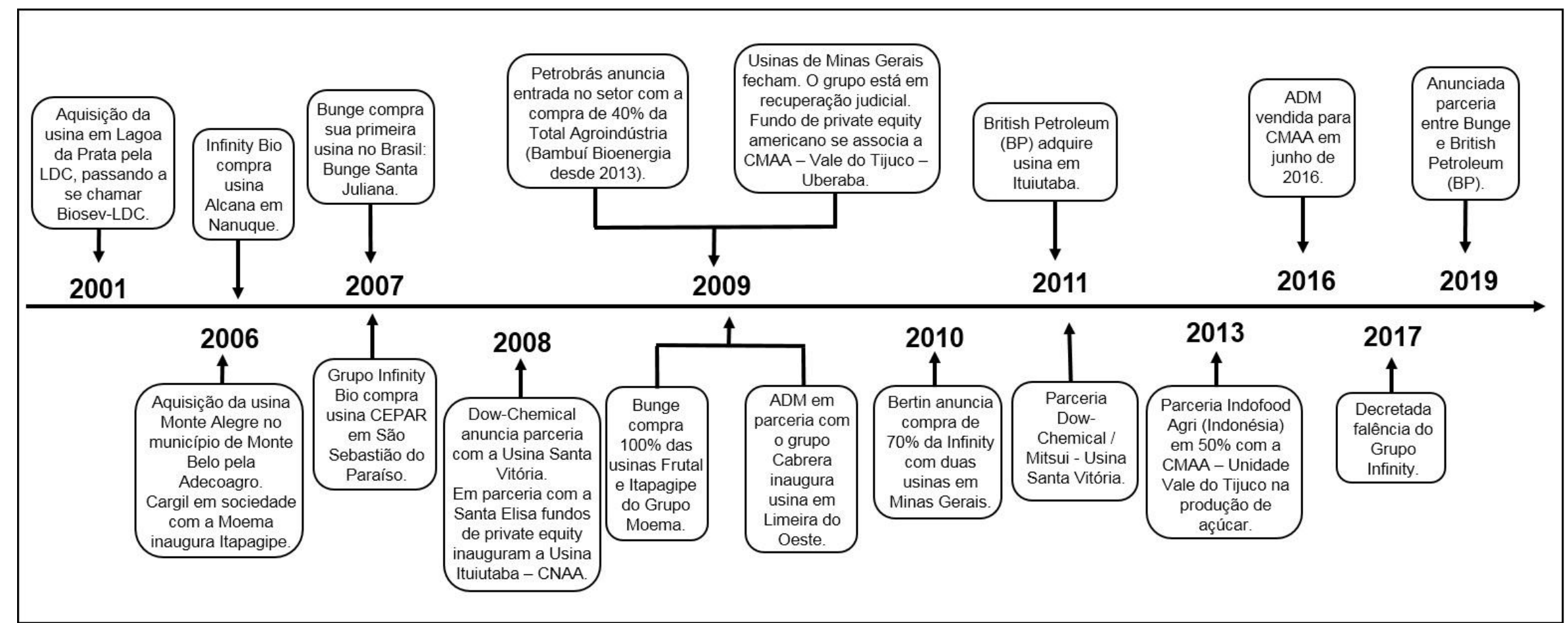

Fonte: SIAMIG, Sites das empresas, Pesquisa de campo (2015 a 2019).

$$
\text { Org.: CAMPOS, N. L., } 2019 .
$$


Além da unidade mineira, a Adecoagro possui duas unidades no Mato Grosso do Sul; a Usina Angélica, construída em 2006 e a Usina Ivinhema, construída em 2011 e situada a $45 \mathrm{~km}$ da Usina Angélica.

Naquele mesmo ano, ocorreu a entrada do Grupo Infinity Bio-Energy, de origem inglesa, no setor sucroenergético mineiro, com a compra da Usina Alcana no município de Nanuque (mesorregião Vale do Mucuri) e, em 2007, adquiriu a Usina Cepar em São Sebastião do Paraíso (mesorregião Sul/Sudoeste de Minas). Ainda, o grupo possui duas usinas no Espírito Santo, uma em Pedro Canário e outra em Conceição da Barra; uma na Bahia em Ibirapuã e outra em Naviraí, no Mato Grosso do Sul.

Desde então, o grupo Infinity vem passando por dificuldades financeiras e suas usinas mineiras fecharam em 2009, e até 2015 apenas três estavam funcionando (MS, BA e uma no ES). Em 2010, o grupo Bertin comprou 70\% da Infinity, porém, não foi capaz de solucionar os problemas financeiros da empresa. Em julho de 2015, com dificuldades para resolver a crise financeira, a companhia pediu autorização para a venda de três de suas seis unidades produtoras, $\mathrm{o}$ arrendamento das usinas restantes e uma renegociação com os credores de uma dívida estimada em mais de $\mathrm{R} \$ 1,9$ bilhão.

Em 2016, a usina localizada em Naviraí (MS) passou a ser controlada por novos gestores, dentre eles a Cargill. O juizado da terceira região do Tribunal Regional Federal em São Paulo decidiu refazer o processo de recuperação judicial da Usinavi (Usina Naviraí), que até o final do mês de abril [2016] estava sendo gerida pela Infinity Bio Energy, de controle acionário (70\%) do grupo Bertin de Lins (SP).

[...] a responsabilidade da gestão deve ser de uma associação feita pelo fundo CarVal, formado por funcionários norte-americanos da multinacional Cargill, e a brasileira Santa Terezinha (que está montando a usina Rio Paraná, em Eldorado). O sonho da CarVal era o decreto de falência para que não gerisse o passivo contábil (dívidas) da massa falida, mas um acordo com os credores, principalmente dos bancos Santander e Banco do Brasil, permitiu a renovação do processo de recuperação judicial. (NOVACANA, 2016).

No ano de 2017 foi decretado pela Justiça a falência do grupo, porém, suas usinas ainda não foram vendidas. De acordo com a reportagem do Portal NovaCana de 2017, a transferência que ocorreu do controle das usinas reduziu a dívida da Infinity, projetada em $\mathrm{R} \$ 2$ bilhões, para menos da metade desse valor. Contudo, a companhia continuou a não pagar suas dívidas, pois quatro usinas restantes estão paradas. Recentemente, em outubro de 2018, a ANP publicou em Diário Oficial que três das quatro unidades do grupo 
Infinity Bio-Energy não poderão mais comercializar o biocombustível. As usinas canceladas já estavam paradas, dentre elas as localizadas em Minas Gerais.

Por sua vez, a mesorregião Triângulo Mineiro/Alto Paranaíba, principal produtora de cana-de-açúcar do estado por concentrar 21 das 35 usinas instaladas, a presença de grupos estrangeiros ocorreu em 2007, quando a Bunge (grupo holandês com sede nos EUA) adquiriu sua primeira usina de cana-de-açúcar localizada em Santa Juliana (MG), que pertencia ao grupo alagoano João Tenório. O grupo não chegou a processar cana na unidade, que pouco tempo depois de sua inauguração foi vendida para a Bunge.

Além desta, outras duas usinas foram adquiridas pela Bunge no estado, uma em Frutal e outra em Itapagipe. Essas usinas pertenciam ao grupo paulista Moema, que descapitalizado diante a crise de 2008, vendeu suas unidades à multinacional. Segundo a revista Exame (2010), a Bunge adquiriu cinco usinas do grupo Moema em 2010, por US\$ 1,5 bi. O negócio foi feito a partir de trocas de ações da Bunge na Bolsa de Nova Iorque pelas do grupo brasileiro. Com o acordo, os acionistas da Moema teriam cerca de $9 \%$ de participação mundial na empresa do agronegócio (EXAME, 2010).

Na ocasião, a Moemapar (holding dos empresários Maurílio Biagi Filho, Eduardo Diniz Junqueira e ainda filhos de Armando Junqueira) obteria cerca de dois terços de participação total no grupo de usinas e controlaria $100 \%$ da unidade Moema, em Orindiúva-SP; na usina de Frutal (MG), o controle é de 56\% e em Itapagipe (MG), de 43,75\%. A estratégia da empresa foi manter aquisições e, até 2011, passou a controlar oito usinas em operação e uma em etapa de finalização.

As usinas de cana-de-açúcar da Bunge no Brasil estão localizadas nos seguintes estados: Minas Gerais, Mato Grosso do Sul, São Paulo e Tocantins. Em Minas Gerais estão as usinas Frutal, Itapagipe e Santa Juliana, em São Paulo as usinas Ouroeste, Guariroba e Moema, em Tocantins a usina Pedro Afonso e, em Mato Grosso do Sul, a usina Monteverde.

Em 2008, houve a entrada do grupo Dow no setor com a aquisição da usina Santa Vitória Açúcar e Álcool, situada no município de mesmo nome. A Dow é um grupo estadunidense que atua nos ramos de inovações e tecnologias através de produtos químicos, plásticos e agropecuários e, segundo informações da empresa, baseados em princípios de sustentabilidade. Ela possui 179 unidades fabris em cerca de 35 países. 
Sua unidade canavieira é subsidiária da Dow Química e ocupa uma posição de destaque na produção de cana da região, com capacidade de produção de 240 milhões de litros de etanol do tipo hidratado e 2,7 milhões de toneladas de cana-de-açúcar por safra, em aproximadamente 40 mil hectares de plantação (DOW-CHEMICAL, 2018). Apesar da usina se chamar Santa Vitória Açúcar e Álcool, ela atua apenas na produção de etanol e energia (Pesquisa de campo - SIAMIG, 2018).

Em 2011 foi criada uma joint venture entre a Dow e a empresa japonesa Mitsui para a produção de bioplásticos ("plástico verde") na unidade Santa Vitória Açúcar e Álcool. De acordo com a revista Exame (2011), o acordo previa parceria com a brasileira Crystalsev, o que não chegou a se concretizar por causa da decisão da Santelisa Vale controladora da Crystalsev - de rever suas operações. Com isso, a joint venture foi firmada com a Mitsui que se tornou parceira com participação de 50\% na operação de cana-de-açúcar da Dow em Santa Vitória. A parceria demandou um extenso projeto de construção na unidade com as operações iniciadas em 2013. Essas empresas já possuíam um histórico de parcerias, tendo formado também uma joint venture na Costa do Golfo americano para a construção de uma unidade de cloro-álcali ${ }^{3}$ em escala mundial. A joint venture formada entre essas empresas durou pouco tempo, sendo encerrada em 2015 com a saída da Mitsui.

Outro grupo que atuou no estado e saiu do setor sucroenergético foi o Archer Daniels Midland - ADM, que em parceria com o ex-ministro da agricultura Antônio Cabrera, inaugurou uma usina no município de Limeira do Oeste (mesorregião Triângulo Mineiro/Alto Paranaíba). A Usina Cabrera Energética foi fundada em 2009 e integrava um projeto maior de construção de duas outras usinas, que nunca saíram do papel. "A usina teve venda anunciada em março de 2016 para a CMAA. As transações foram concluídas em julho de 2016, após a aprovação pelos órgãos reguladores" (NOVACANA, 2016).

Atuando no setor de energia, sobretudo de petróleo e gás, a British Petroleum BP está presente no estado desde 2011, quando adquiriu uma unidade no município de Ituiutaba, que pertencia a Companhia Nacional de Açúcar e Álcool - CNAA. No setor sucroenergético brasileiro, a BP iniciou sua participação em 2008, quando se tornou sócia da Tropical Bioenergia, usina situada no município de Edéia, Goiás, com participação de 50\%. No último trimestre de 2011, a BP anunciou a aquisição do restante das ações, assumindo o controle operacional da Tropical e em 2014 foi concluída a expansão da 
unidade, dobrando sua capacidade de moagem. Sua segunda unidade, também localizada no estado de Goiás, em Itumbiara, teve a conclusão de sua construção em 2008, com capacidade para moer até 2,5 milhões de toneladas de cana-de-açúcar por ano. Com a unidade mineira, o grupo possui 3 usinas no país.

As usinas da BP no Brasil são constituídas integralmente por capital estrangeiro. Sua presença no Triângulo Mineiro/Alto Paranaíba, além de localizar próximo as outras duas unidades de Goiás, se deve principalmente devido a "oferta e qualidade das áreas agricultáveis e o custo de contratos de parceria mais baixo que em regiões tradicionais (estados de SP e PR)" (Pesquisa de campo, 2018). Assim, a região tornou-se para muitos investidores do setor sucroenergético uma opção mais barata para a produção canavieira, já que as áreas tradicionais estavam saturadas e com elevado custo.

Nesse sentido, o cenário que se desenha da internacionalização do setor sucroenergético no estado de Minas Gerais é demonstrado no quadro 1.

Quadro 1: Relação das usinas sucroenergéticas com participação de capital estrangeiro em Minas Gerais (2019)

\begin{tabular}{|c|c|c|c|c|}
\hline \multicolumn{5}{|c|}{ Usinas controladas por Grupos Estrangeiros em Minas Gerais - atuantes } \\
\hline Grupo Estrangeiro & Nome da Usina & Município & $\begin{array}{c}\text { Ano de } \\
\text { aquisição }\end{array}$ & $\begin{array}{l}\text { Origem do } \\
\text { Capital }\end{array}$ \\
\hline Adecoagro & Usina Monte Alegre & Monte Belo & 2006 & Argentina \\
\hline \multirow{3}{*}{ Bunge } & Bunge - Frutal & Frutal & 2007 & \multirow{3}{*}{$\begin{array}{c}\text { EUA/ } \\
\text { Holanda }\end{array}$} \\
\hline & Bunge - Itapagipe & Itapagipe & 2006 & \\
\hline & Bunge - Santa Juliana & Santa Juliana & 2007 & \\
\hline British Petroleum - BP & Ituiutaba & Ituiutaba & 2011 & Reino Unido \\
\hline $\begin{array}{c}\text { Dow Chemical \& } \\
\text { Mitsui }\end{array}$ & Santa Vitória & Santa Vitória & 2009 & EUA/Japão \\
\hline $\begin{array}{l}\text { Louis Dreyfus } \\
\text { Company }\end{array}$ & $\begin{array}{l}\text { LDC-SEV - Lagoa da } \\
\text { Prata }\end{array}$ & Lagoa da Prata & 2001 & França \\
\hline \multicolumn{5}{|c|}{ Usinas com parceria de Grupos Estrangeiros em Minas Gerais - atuantes } \\
\hline Indofood Agri & $\begin{array}{l}\text { CMAA - Vale do } \\
\text { Tijuco }\end{array}$ & Uberaba & 2013 & $\begin{array}{c}\text { Brasil/ } \\
\text { Indonésia }\end{array}$ \\
\hline Petrobrás/ Total & Bambuí Bioenergia & Bambuí & 2006 & Brasil/França \\
\hline \multicolumn{5}{|c|}{ Usinas de Grupo Estrangeiro em Minas Gerais - não atuantes e/ou em recuperação judicial } \\
\hline $\begin{array}{c}\text { Archer Daniels } \\
\text { Midland - } \text { ADM }^{(1)}\end{array}$ & Usina Cabrera & Limeira do Oeste & 2008 & EUA \\
\hline \multirow{2}{*}{ Infinity Bio Energy ${ }^{(2)}$} & Destilaria Alcana & Nanuque & 2006 & \multirow{2}{*}{ EUA } \\
\hline & Cepar - Paraíso & São Sebastião do Paraíso & 2006 & \\
\hline
\end{tabular}

(1) Usina Cabrera comprada pela CMAA em 2016.

(2) Usinas do Grupo Infinity Bio Energy em Minas Gerais estão em recuperação judicial desde 2008.

Fonte: União dos Produtores de Bioenergia (UDOP); Sindicato da Indústria de Fabricação do Álcool no Estado de Minas Gerais (SIAMIG), NovaCana, INFOCANA e Site das empresas, 2019.

Org. CAMPOS, N. L., 2019. 
Além da gestão majoritária e, em alguns casos, total de multinacionais em usinas do setor, ocorreram também associação de capital externo em algumas unidades no estado, como é o caso da Petrobrás com o grupo francês Total na usina Bambuí e a parceria para a produção de açúcar da Indofood Agri da Indonésia com a CMAA unidade Vale do Tijuco em Uberaba. Nesse último caso, a Indofood Agri detém 50\% do capital da usina.

Em dezembro de 2019 foi criada a BP Bunge Bioenergia, uma joint venture entre os grupos que combina seus negócios de bioenergia e etanol no Brasil (JornalCana, 2019). Com isso, as empresas terão representação igual no conselho administrativo. Essa união de grandes grupos estrangeiros é também uma estratégia de controle e representatividade no setor sucroenergético, pois as empresas passaram a controlar 11 usinas no país, localizadas nas regiões Sudeste, Centro-Oeste e Norte, em cinco estados brasileiros.

Assim, há um rápido avanço do capital estrangeiro no setor sucroenergético, representado pelas multinacionais que se associaram aos grupos nacionais, transformando as usinas em gigantes unidades agroindustriais, ampliando sua capacidade de produção e incorporando novos territórios na atividade canavieira. A mesorregião Triângulo Mineiro/Alto Paranaíba é um exemplo da expansão canavieira e da presença estrangeira no controle de usinas.

Todas as usinas estrangeiras da região são de atuação recente - da década de 2000, portanto, mais modernas em relação às primeiras instaladas no estado. À medida que a expansão canavieira acelerou na região, novos municípios foram inseridos nesta atividade. O que ocorreu desde o início do século XXI foi uma absorção dos territórios para a produção canavieira e a presença dos grupos estrangeiros reforçam uma expropriação do capitalista pelo capitalista, que transformam capitais pequenos em grandes capitais. Conforme Sposito e Santos (2012, p. 19), configura-se em um "processo que pressupõe apenas a alteração dos capitais já existentes e não está atrelado ao aumento da riqueza social ou aos limites da acumulação". Com isso, as grandes empresas (multinacionais) passaram a ter um controle maior da estrutura de empresas nacionais que já eram consolidadas no país como uma empresa capitalista. 


\section{Interesses e implicações da internacionalização do setor sucroenergético na mesorregião Triângulo Mineiro/Alto Paranaíba}

A expansão recente da cultura canavieira no Triângulo Mineiro/Alto Paranaíba ocorreu através de uma série de elementos e instrumentos que a tornou produtiva e rentável na região, provocando transformações profundas na base socioprodutiva regional. A capacidade socioprodutiva da região, incluindo aspectos naturais, além do preço das commodities agrícolas no cenário internacional, foram fatores importantes que despertaram o interesse de grupos estrangeiros no setor sucroenergético mineiro.

A mesorregião do Triângulo Mineiro/Alto Paranaíba está localizada em um bioma cujos fatores naturais (climáticos, relevo e principalmente disponibilidade hídrica) favoráveis à agricultura moderna e mecanizada. Situada à margem dos rios Grande e Paranaíba e com disponibilidade de terras para incorporação agrícola, uma vez que há amplas áreas exploradas com a pecuária e pastagens degradadas, a região reúne os principais elementos para a produção canavieira, por isso o número elevado de usinas instaladas.

Nas atividades inerentes ao agronegócio, o território é um fator importante para a consolidação de uma agricultura globalizada. Sendo o território "fruto das relações sociais e de poder" (HAESBAERT, 2004), observamos uma monopolização da terra e da água pelo capital para a agricultura de exportação. Na produção de commodities agrícolas como a cana-de-açúcar, o uso da água é essencial. Diante disto, presenciamos disputas territoriais que vão além do acesso à terra e a expropriação camponesa para o crescimento do agronegócio. Estamos diante de uma disputa pelo acesso às melhores terras que contemplem todo o aparato necessário para a produção canavieira: terras férteis e água.

\footnotetext{
A dinâmica dos negócios agropecuários, particularmente vinculados à expansão e consolidação da cana-de-açúcar, das plantas agroprocessadoras, na medida de sua estreita vinculação à apropriação privada da terra e das fontes de água ou dos recursos hídricos, estimula-nos a operar/aperfeiçoar o conceito de agronegócio. Ou seja, o sucesso do agronegócio não pode ser atribuído somente à sua fixação à territorialização e/ou monopolização das terras, mas também ao acesso e controle da água, assim como as demais etapas da cadeia produtiva, comercialização etc. (THOMAZ JUNIOR, 2012, p. 11).
}

Benko e Pecqueur (2001) ao referirem-se aos territórios buscados pelas multinacionais revela que são espaços que oferecem recursos específicos, intransferíveis e incomparáveis no mercado, que diversificam os espaços e estabilizam as localizações das atividades econômicas. Esses espaços sofrem constantes processos de 
territorialização e disputas territoriais entre agronegócio e agricultura familiar/camponesa, que nos remete a questão agrária existente - os embates entre essas duas formas de produção, assim como as disputas territoriais que marcam o processo de produção agrícola atual.

A respeito das disputas territoriais relacionadas a terra e a água, o agronegócio tem se imposto ao incorporar as melhores terras para sua reprodução, terras essas pertencentes a produtores que aos poucos foram inseridos na agricultura globalizada. Tal fator ocorreu no setor sucroenergético da região, no qual a incorporação dos territórios pela agroindústria canavieira se deu em grande parte por meio de arrendamentos e pouco em terras próprias das usinas. Existe também a presença do fornecedor, que realiza o plantio em terras próprias e vendem para as usinas.

[...] hoje cada vez mais ocorre um processo de "terceirização" do plantio da cana de açúcar, com a existência de contratos entre produtores e usinas ou, também de forma subordinada, o estabelecimento de contratos de arrendamento por longos períodos e com clara situação de dependência dos proprietários de terras em relação às usinas e grupos que controlam a produção de açúcar e álcool na região. (PEREIRA, 2012, p. 97).

A Bunge, por exemplo, faz contratos de arrendamentos por oito anos e, de acordo com entrevistado, quem arrenda para a usina não arrenda para mais ninguém, devido a sua forma de pagamento. Ela paga à vista, ela paga por mês, ela paga bem mais que um produtor de lavoura branca 4 (Entrevistado Sindicato dos Trabalhadores Rurais de Santa Juliana, setembro de 2018).

Quando a usina arrenda uma terra, ela faz todo o preparo para o plantio da cana, é responsável pelo cultivo e colheita durante todo o período do contrato. Porém, o que retorna ao proprietário quando desistem do arrendamento é uma terra degradada e improdutiva, pois o valor para correção dessas terras é muito alto, ficando com o proprietário apenas o prejuízo.

Há uma disputa territorial por terras entre usinas e produtores, e a ampliação das áreas cultivadas com cana demonstra o interesse do setor sucroenergético na região. A tabela 1 mostra como a área plantada de cana e sua produção teve um crescimento rápido desde a década de 1990. 
Tabela 1: Triângulo Mineiro/Alto Paranaíba - área plantada, área colhida e quantidade produzida de cana-de-açúcar (1994-2018)

\begin{tabular}{cccc}
\hline Anos & $\begin{array}{c}\text { Área Plantada } \\
\text { (hectares) }\end{array}$ & $\begin{array}{c}\text { Área Colhida } \\
\text { (hectares) }\end{array}$ & $\begin{array}{c}\text { Quantidade Produzida } \\
\text { (toneladas) }\end{array}$ \\
\hline 1994 & 86.084 & 86.084 & 6.307 .135 \\
1998 & 105.753 & 105.753 & 8.197 .970 \\
2002 & 118.636 & 118.636 & 8.922 .843 \\
2006 & 251.920 & 251.920 & 20.521 .710 \\
2010 & 492.440 & 492.440 & 42.415 .800 \\
2014 & 664.735 & 648.921 & 51.392 .433 \\
2018 & 651.497 & 647.497 & 51.814 .167 \\
\hline
\end{tabular}

Fonte: Produção Agrícola - PA (IBGE, 2019)

Org.: CAMPOS, N. L., 2019.

A esse respeito, Santos (2017) aponta que a região conheceu uma grande ampliação geográfica do agronegócio canavieiro, que transformou completamente a paisagem rural de vários municípios numa imensidão de canaviais.

Em Uberaba/MG, maior produtor de cana-de-açúcar da mesorregião, por exemplo, a área plantada aumentou de 5 mil hectares em 2000 para 73,7 mil hectares em 2015. Em Frutal/MG, segundo maior produtor, a área plantada com cana-de-açúcar passou de 3,6 mil para 61,9 mil hectares. Em Santa Vitória/MG, terceiro maior produtor, a expansão foi de 40 hectares para 53,5 mil hectares. E em Campo Florido/MG, quinto maior produtor, a lavoura ampliou-se de 800 hectares para quase 32 mil hectares no mesmo período. (SANTOS, 2017, p. 91).

O autor fez um levantamento dos dez maiores municípios com área plantada de cana-de-açúcar a partir dos dados da produção agrícola municipal levantados pelo IBGE, sendo eles: 1-Uberaba; 2-Frutal; 3-Santa Vitória; 4-Conceição das Alagoas; 5-Campo Florido; 6-Iturama; 7-Ituiutaba; 8-Limeira do Oeste; 9-Conquista e 10-Água Comprida (SANTOS, 2017). Assim, percebemos/constatamos que as usinas estrangeiras da região estão localizadas em municípios considerados maiores produtores de cana. Somente as unidades da Bunge em Santa Juliana e Itapagipe não estão nesta seleção, o que demonstra a importância geoestratégica da região no processo de internacionalização do setor.

$\mathrm{O}$ crescimento da produção canavieira em Minas Gerais provocou mudanças na paisagem rural e uma série de implicações na produção agrícola. De acordo com Stacciarini (2019), alguns municípios do Triângulo Mineiro/Alto Paranaíba, sobretudo os menos populosos, tornam-se mais sensíveis aos efeitos da expansão da cana, uma vez que esta acarretará inúmeros processos socioterritoriais nestes municípios, "seja no que diz respeito ao espaço rural, e mesmo no que tange às suas atividades urbanas, em geral também muito acionadas para o trabalho no setor (STACCIARINI, 2019, p. 57). São municípios com alto grau de subordinação e dependência da atividade sucroenergética, 
sobretudo na reprodução do trabalho, tais como Araporã, Campo Florido, Carneirinho, Conceição das Alagoas, Conquista, Delta, Itapagipe, Iturama, Limeira do Oeste, Pirajuba e Santa Vitória.

\begin{abstract}
Tais espaços [...] se caracterizam, em muito, pelo alto grau de especialização produtiva voltada ao setor sucroenergético. Destaca-se que todos eles contam com uma ou mais unidade produtiva (usina) ativa em seu espaço territorial, além de possuírem, em média, $76,8 \%$ de suas áreas destinadas à agricultura (temporária e permanente) ocupadas com canaviais - embora esse número oscile entre $97,3 \%$ e $47,2 \%$. A abrangência da cultura e o grau de especialização produtiva se tornam ainda mais preocupantes por se tratar de municípios pouco populosos (com razão populacional média de 14,1 mil hab., embora tenham representantes oscilando entre 5,7 mil e 38,5 mil hab.). (STACCIARINI, 2019, p. 60).
\end{abstract}

Os grupos estrangeiros presentes na região atuam em municípios com elevado índice de produção de cana, seja em municípios especializados, seja em municípios maiores produtores, como apontado por Santos (2017). As usinas estrangeiras possuem elevado grau de desenvolvimento científico e tecnológico. Segundo Guimarães (2000), a principal vantagem das megaempresas multinacionais em sua competição com as demais empresas seria sua superior capacidade de organização das atividades empresariais. Com isso, afirma que "o capital e a empresa estrangeira contribuiriam para modernizar as práticas empresariais brasileiras e para tornar as empresas brasileiras mais competitivas e eficientes, interna e externamente" (GUIMARÃES, 2000, p. 151).

Para Oliveira (2012), a criação das empresas mundiais, por meio de abertura de filiais, fusões, aquisições e associações, foi viabilizada graças a esses avanços na área tecnológica, que possibilitaram a comunicação e integração entre as unidades industriais em diferentes partes do mundo. Como muitos grupos, a BP também deu preferência ao processo de fusões e aquisições, procurando usinas já ativas no país, evitando grandes construções com alto nível de investimento. De encontro a esses fatores, as áreas com boa qualidade de produção e a grande quantidade de fazendas vizinhas também foram pontos determinantes para a BP comprar a usina situada em Ituiutaba ${ }^{6}$.

Assim, "os grupos estrangeiros utilizam seu capital excedente, descrito por Marx como mais-valia, reaplicando-o em novos mercados, novos meios de produção modernização, ampliação da escala de produção etc." (SPOSITO; SANTOS, 2012, p. 18).

Para sua consolidação, as multinacionais têm por objetivo a apropriação dos territórios para a produção de commodities, expandindo seu capital e alcançando novos mercados. 
A participação dessas novas empresas no setor sucroenergético exigiu a exploração de novas áreas para o plantio da cana-de-açúcar, com condições técnicas e normativas mais favoráveis para a produção de açúcar e etanol. Essa nova realidade pode ser verificada pela maior participação da região CentroOeste quanto à área plantada e colhida de cana-de-açúcar. (VENCOVSKY, 2013, p. 53-54).

Com isso, o crescimento da cana na região tem gerado uma série de preocupações em relação às áreas em que ela está ocupando. Por ser uma região tradicionalmente voltada à agropecuária, questiona-se que a cana-de-açúcar está disputando espaços com outras lavouras (cultivos alimentares) e gerando conflitos territoriais com produtores da região.

Outro ponto conflitante do avanço da cana-de-açúcar é a concentração e o impacto no mercado de terras. Quanto mais cresce a produção de commodities no país, cresce também a demanda por terras na expansão da fronteira agrícola e, consequentemente, um aumento dos conflitos territoriais. Segundo Sauer (2011, p. 16), “apesar de não ser um fenômeno inédito, o campo brasileiro está vivenciando um novo ciclo de expansão do capital, resultando no avanço das fronteiras, alta dos preços das terras e acirramento dos conflitos fundiários e territoriais".

O processo de internacionalização, além de configurar uma nova dinâmica produtiva ao setor, tem demonstrado nos últimos anos uma alteração no preço da terra, gerando novas implicações territoriais, sobretudo à produção agropecuária de pequenos e médios produtores regionais. O uso do território para práticas capitalistas de produção tem como efeito uma valorização das terras e, consequentemente, concentração das mesmas nas mãos de grandes proprietários, dificultando a reprodução camponesa. A esse respeito, Souza (2013) relata que houve uma mudança do paradigma conceitual da terra de trabalho por terra de negócio.

\begin{abstract}
A análise de mercados de terras revela a relação entre o desenvolvimento capitalista no Brasil e a apropriação de terras agrícolas, evidenciando o processo de modernização, as políticas fiscais, cambiais e tributárias como fatores determinantes na consolidação/permanência da aristocracia agrária brasileira. A análise tem importância devido aos índices de concentração da propriedade e da posse da terra; à evolução da produtividade agrícola. Ressalta-se, igualmente, os grandes conflitos fundiários e sociais no campo, engendrados por tal processo. (SOUZA, 2013, p. 31).
\end{abstract}

A expansão canavieira em Minas Gerais ocasionou um impacto no mercado de terras, sobretudo na mesorregião do Triângulo Mineiro/Alto Paranaíba onde as terras foram altamente valorizadas devido aos investimentos agroindustriais. O Triângulo 
Mineiro é uma das regiões em que as propriedades rurais estão entre as mais caras do país. A capacidade produtiva das terras é o principal argumento do aumento do preço das mesmas no estado, além do crescimento contínuo da demanda por alimentos e matériasprimas agropecuárias no mundo, que sustentou a valorização nos últimos 10 anos.

No Alto Paranaíba (região de Araxá), Sul de Minas (região de Pouso Alegre) e Triângulo (região de Uberlândia) estão as terras de lavouras mais caras do Estado (com preço médio de $\mathrm{R} \$ 20.291,75$ na primeira, $\mathrm{R} \$ 16.506,60$ na segunda região e R\$ 16,404,37 na terceira). (RURALBR, 2013).

Dentre os fatores que interferem no preço da terra, Souza (2013, p. 34) destaca as ações do Estado por meio de políticas agrárias, de crédito rural, de distribuição de terra e de incentivo à produção agrícola; e os fatores "determinados internos da agricultura", como a capacidade produtiva da terra, os preços de commodities e insumos, entre outros.

De acordo com Delgado (2012), o agronegócio no Brasil significa uma associação do grande capital agroindustrial com a grande propriedade fundiária, que realiza uma estratégia econômica de capital financeiro perseguindo o lucro e a renda da terra, sob patrocínio de políticas de Estado. Portanto, a terra é tida como um ativo gerador de lucro para os grandes grupos econômicos que comandam a produção agrícola do país.

Assim, o preço da terra é a expressão empírica da expectativa da renda da terra capitalizada, calculada pelos agentes de mercado em cada conjuntura (DELGADO, 2012, p. 97).

[...] a formação do preço da terra e a apropriação de terras públicas ou privadas sempre se constituíram nos ciclos fortes de expansão agrícola, como o atual, em processos peculiares de associação dos grandes proprietários com as agências de Estado, encarregadas da política fundiária. Esses processos irão se repetir na década de 2000, sob novas roupagens, mas fundamentalmente com o mesmo sentido. E isto irá configurar ao setor de agronegócio um campo peculiar de valorização de sua riqueza, propiciada pelo boom das commodities e alavancada, para usar uma expressão tão ao gosto do sistema financeiro, pela frouxidão da política fundiária. (DELGADO, 2012, p. 99).

Sauer (2011) destaca que o crescimento da produção agrícola e, consequentemente, das demandas e transações de compra de terras, concentra-se na expansão de oito commodities, sendo elas: milho, soja, cana-de-açúcar, arroz, dendê (óleo), canola, girassol e floresta plantada. Destaca que a participação brasileira se dá fundamentalmente nos três primeiros produtos, segundo o Banco Mundial (2010). Esse crescimento está diretamente vinculado à produção de matérias-primas para os agrocombustíveis em função da crescente procura por fontes alternativas de energia (SAUER, 2011, p. 16). 
De acordo com o autor, parte significativa dos investimentos estrangeiros no Brasil, inclusive na compra de terras, são financiados com recursos públicos, especialmente oriundos do Banco Nacional de Desenvolvimento Econômico e Social (BNDES) e dos Fundos Constitucionais do Centro-Oeste (FCO) e do Norte (FNO) e estão sendo destinados principalmente à expansão do cultivo de cana, para a produção de etanol (no Cerrado de Goiás, Mato Grosso do Sul e Triângulo Mineiro) e da soja (região conhecida como Matopiba, mas também em partes da Região Amazônica), bem como à extração de minérios e madeira (especialmente na Região Amazônica) (SAUER, 2011, p. 17).

Acrescido a esse processo, houve uma valorização das terras em Minas Gerais entre 2002 e 2012, com variação no Índice de Preço de Terras - IPT de 530\%. [...] "no Alto Paranaíba a valorização no período (2002 a 2012) foi de $310 \%$ e no Triângulo Mineiro de 290\%, ficando atrás apenas, em termos de valorização, da região do Vale do Rio Doce, que teve expressivos 670\% de aumento". (BEILER, 2017, p. 34).

[...] no ano 2013, a elevação foi considerável: as terras do Alto Paranaíba foram as mais valorizadas do estado, custando, em média $\mathrm{R} \$ 20,291$ mil por hectare, $13,97 \%$ a mais que no ano anterior, quando o preço médio era de $\mathrm{R} \$ 17,8 \mathrm{mil} / \mathrm{ha}$. No Triângulo Mineiro a alta foi de $20,1 \%$ no mesmo ano, com o preço médio do hectare avaliado em R\$ 16, 404 mil (FAEMG, 2014 apud Portal do Economista, 2014). No mesmo ano o aumento do preço médio da terra no país foi de $14,9 \%$. (BEILER, 2017, p. 34).

A tabela 2 demonstra como essa variação ocorreu em municípios que ocorre o cultivo da cana-de-açúcar na mesorregião Triângulo Mineiro/Alto Paranaíba/MG. De 2011 a 2016 houve um aumento de mais de $80 \%$ em quase todas as áreas descritas.

Tabela 2: Cana-de-acúcar - Preço da terra (R \$/ha.) cultivada com cana-de-açúcar em municípios da mesorregião Triângulo Mineiro/Alto Paranaíba/MG (2011-2016)

\begin{tabular}{lccccccc}
\hline \multicolumn{1}{c}{ Região/ Município } & $\begin{array}{c}\text { Capacidade de } \\
\text { produção }\end{array}$ & Unidade & $\mathbf{2 0 1 1}$ & $\mathbf{2 0 1 5}$ & $\mathbf{2 0 1 6}$ & $\Delta \mathbf{1 6 / 1 1}$ & $\Delta \mathbf{1 6 / 1 5}$ \\
\hline Água Comprida & Média & $90 \mathrm{t}$ cana/ha & 13.083 & 24.000 & 24.000 & $83,4 \%$ & $0,0 \%$ \\
Conceição das Alagoas & Média & $95 \mathrm{t}$ cana/ha & 13.083 & 24.000 & 24.000 & $83,4 \%$ & $0,0 \%$ \\
Ituiutaba* & Alta & $80 \mathrm{t} \mathrm{cana} / \mathrm{ha}$ & 9.417 & 16.500 & 17.500 & $85,8 \%$ & $6,1 \%$ \\
Ituiutaba** & Baixa & $60 \mathrm{t}$ cana/ha & 7.367 & 13.000 & 13.000 & $76,5 \%$ & $0,0 \%$ \\
Uberaba & Média & $95 \mathrm{t}$ cana/ha & 12.200 & 23.417 & 23.000 & $88,5 \%$ & $-1,8 \%$ \\
\hline
\end{tabular}

* Área plana/Solo argiloso

** Solo arenoso

Fonte: Anuário da Agricultura Brasileira, 2017.

Org.: CAMPOS, N. L., 2018.

É notável que o cultivo da cana na região gerou um aumento no preço das terras, mesmo que no período de crise financeira esse aumento esteve retraído, porém, a 
produção de grãos, sobretudo soja e milho, e áreas de pastagens são as principais responsáveis por elevar o valor das terras mineiras. Segundo Souza (2013), a demanda por terra altera seu valor em função de sua incorporação pelos grandes complexos agroindustriais, particularmente o setor sucroenergético, o que resulta em processos de concentração e de homogeneização do território e da paisagem.

Beiler (2017) afirma que a necessidade das usinas estarem localizadas nas proximidades das áreas de cultivo da cana, implica numa valorização imediata do preço dessas terras em seu entorno. Ainda, há a vantagem de diminuir os custos com transporte da produção, aumentando o lucro das empresas.

Assim, corroboramos que no interior da crise financeira, o setor sucroenergético aproveitou-se das discussões ambientais e crise energética, como forma de ampliar sua reprodução através da produção de agrocombustíveis. O interesse nos agrocombustíveis é o elemento chave para compreender a fase atual da corrida mundial por terras. As crises do petróleo têm desencadeado uma preocupação em relação ao futuro energético, resultando num crescimento em busca de fontes alternativas de energia, como os agrocombustíveis.

Assim, grupos como Louis Dreyfus, Cargill, British Petroleum, Tereos, Bunge, Adecoagro etc., estão presentes no setor sucroenergético brasileiro desde o início dos anos 2000, ampliando através de aquisições de novas unidades, fusões com grupos estrangeiros e nacionais, controlando diversas porções do território brasileiro e da produção agropecuária.

A atuação desses grupos se dá através do monopólio da terra e demais recursos naturais, em que os arrendamentos são a principal forma de controle das terras brasileiras por empresas estrangeiras. A opção por arrendamentos que empresas do setor sucroenergético realizam justifica-se pelos menores custos de produção, pois os contratos de parceria e a compra de matéria-prima de terceiros (fornecedores) é mais vantajoso, por isso essa prática é predominante nas usinas do país.

Com o crescimento da demanda por agrocombustíveis, há uma tendência de aumento das áreas cultivadas com cana-de-açúcar, sobretudo nesses territórios em que a produção está consolidada. Com isso, haverá a necessidade de incorporação de novos territórios, acarretando prejuízos a produção agropecuária que está cada vez mais perdendo espaço para a produção de agroenergia, implicando na reprodução camponesa. 
O Estado brasileiro vem privilegiando processos de desenvolvimento econômico baseados na expropriação e acumulação de terras desde a sua modernização. Esse processo é considerado predatório, excludente e concentrador, pois resulta na concentração da propriedade da terra - principal causa dos conflitos no campo. Esse modelo produtivo agroexportador, oriundo de uma modernização conservadora afeta sobretudo grupos sociais do campo através de sua constante manutenção.

\section{Considerações finais}

A incorporação de capital estrangeiro proveniente das multinacionais a partir dos anos 2000, é um fato que ocorreu, sobretudo com o desencadeamento de uma crise financeira fortemente sentida pelo agronegócio canavieiro no ano de 2008, e que definiu o desenvolvimento da atividade por grupos e empresários financeiramente mais preparados para enfrentar situações de crise. A internacionalização do setor sucroenergético é também vista como uma forma de garantir a sobrevivência de usinas que não conseguiram superar as sucessivas crises, abrindo seu capital para investimentos estrangeiros, passando a ser controlada por multinacionais.

Esse controle acontece em todas as etapas do processo produtivo. Elas são responsáveis pela produção até a logística de escoamento das safras e transformação agroindustrial. Nesse sentido, há uma territorialização dos monopólios com um maior controle da propriedade da terra e os grupos atuam através de uma monopolização dos territórios, controlando o processo produtivo através de mecanismos de subordinação.

A opção do Estado em valorizar o agronegócio brasileiro tem provocado uma série de implicações territoriais no campo, impactando a agricultura familiar e os pequenos produtores, reduzindo as áreas destinadas à produção de alimentos e alterando o valor do preço da terra. A expansão da produção de agrocombustíveis no mundo tem acirrado as disputas territoriais, e como consequência, elevado o preço dos alimentos básicos como o milho, o arroz e o trigo. A opção do Estado brasileiro em aproveitar-se desse momento e fortalecer o setor sucroenergético trouxe como consequência a redução das áreas dos cultivos alimentares, enquanto a área plantada com cana-de-açúcar registrou crescimento desde a década de 1990.

Assim, os interesses das corporações multinacionais têm sido produzir em lugares que oferecem vantagens, sobretudo com a redução de custos e incremento tecnológico. $\mathrm{O}$ 
Brasil é esse lugar devido a sua experiência na atividade sucroenergética, estimulada desde o Proálcool e intensificada com o desenvolvimento dos automóveis flexfuel, portanto, é uma opção mais barata e lucrativa para esses grupos.

Observamos uma monopolização e controle do território como estratégia do processo de internacionalização, que tem intensificado a especialização produtiva desses territórios acionados para o cultivo da cana, como em diversas regiões do estado de Minas Gerais, e consolidado o poder de empresas estrangeiras no setor sucroenergético.

A expansão do capital estrangeiro, sobretudo naquelas atividades ligadas ao controle da terra, como o agronegócio, representa mais uma das estratégias de reprodução ampliada do capital refletindo, assim, sua necessidade em sua lógica expansionista de incorporar novos territórios. Esses capitais associados às transnacionais e aos grandes proprietários de terras dominam a agricultura no Brasil, modificam a estrutura e impõem um modelo altamente tecnológico na produção, o que pode elevar os prejuízos, sobretudo aos pequenos produtores, dificultando o acesso à terra. Por trás dessa expansão, temos o Estado brasileiro agindo a favor do agronegócio através de incentivos e políticas públicas, amparando o setor frente as crises econômicas. O processo de estrangeirização segue dinâmica da financeirização da riqueza. A compra de terras é uma das principais, que compreende ainda a captura dos recursos naturais, biodiversidade e demais componentes do espaço agrário

\section{Agradecimentos}

Agradecemos a Coordenação de Aperfeiçoamento de Pessoal de Nível Superior - CAPES pela bolsa do PNPD e ao CNPq pelo apoio às pesquisas por meio do Chamada MCTIC/CNPq No 28/2018.

\section{Notas}

\footnotetext{
${ }^{1}$ A base de divisão espacial adotada na pesquisa compreende a Mesorregião Geográfica (MRG) aqui denominada de Triângulo Mineiro como sendo a MRG Triângulo Mineiro/Alto Paranaíba (IBGE, 1989).

${ }^{2}$ É uma rede global de firmas independentes que prestam serviços profissionais de Audit, Tax e Advisory. Estão presentes em 157 países.

${ }^{3}$ Cloro-álcali (CA) refere-se à fabricação de cloro e soda cáustica $(\mathrm{NaOH})$. Estes estão entre os dez principais produtos químicos produzidos em todo o mundo e são ingredientes principais na fabricação de produtos farmacêuticos, detergentes, desinfetantes, herbicidas, pesticidas e PVC. Cloro e soda cáustica são feitos pela eletrólise da salmoura $(\mathrm{NaCl})$. 〈https://www.magnetrol.com/pt/processo-de-cloro-alcali>.

${ }^{4}$ Lavoura que não é perene, precisa ser plantada todos os anos, como exemplo: milho, algodão, arroz etc.

${ }^{5}$ Dados crescentes de forma a contemplar o início da década de 1990 até o último ano de registro (2018) do IBGE.

${ }^{6}$ Pesquisa de campo, julho de 2018.
} 


\section{REFERÊNCIAS}

ALMEIDA, M. C.; GUIDA, L. C. Renda da terra e setor sucroenergético brasileiro: as estratégias territoriais da Adecoagro. In: BERNARDES, J. A.; FREDERICO, S.;

GRAS, C.; HERNÁNDEZ, G. M. (Org.). Globalização do Agronegócio e Land

Grabbing: a atuação das megaempresas argentinas no Brasil. Rio de Janeiro:

Lamparina, 2017, 184 p. p. 159-177.

BELIER, R. R., Impactos do setor sucroenergético sobre o preço das terras no Triângulo Mineiro. 2017. 46 f. Monografia - Instituto de Geografia, UFU, Uberlândia, 2017.

BENNETI, M. D. A internacionalização recente da indústria de etanol brasileira. Indicadores Econômicos FEE. Porto Alegre, v. 36, nº 4, 2008.

BENKO, G; PECQUEUR, B. Os recursos de territórios e os territórios de recursos. Revista Geosul. Florianópolis, p. 31-50, 2011.

CAMPOS, N. L., Internacionalização do capital no setor sucroenergético do Triângulo Mineiro/Alto Paranaíba: estratégias políticas e territoriais. 2019. $258 \mathrm{f}$. Tese (Doutorado em Geografia e Gestão do Território) - Instituto de Geografia, UFU, Uberlândia, 2019. http://dx.doi.org/10.14393/ufu.te.2019.631

CLEPS JUNIOR, J. Políticas de produção e expansão de agrocombustíveis no Brasil e os efeitos nas áreas de cerrados de Minas Gerais. In: Encontro de Geógrafos da América Latina - EGAL. Havana, Anais... Havana, 2015. ICD-ROM.

CONCLUÍDA a formação da BP Bunge Bioenergia, 2 de dezembro de 2019. JORNAL CANA. Disponível em: <https://jornalcana.com.br/concluida-a-formacao-da-bp-bungebioenergia/>. Acesso em: 05 de dezembro de 2019.

DELGADO, G. C. Do capital financeiro na agricultura à economia do agronegócio: mudanças cíclicas em meio século [1965-2012]. Porto Alegre: Editora da UFRGS, 2012, 144 p.

DIREITOS humanos no Brasil 2012. MERLINO, T., MENDONÇA, M. L. (Orgs.) Relatório da Rede Social de Justiça e Direitos Humanos. São Paulo, 2012, 224 p.

DOMINGUES, A. T. A territorialização do grupo agroindustrial canavieiro Louis Dreyfus no Mato Grosso do Sul. 2010. 200 f. Dissertação (Mestrado em Geografia) UFGD, Dourados, 2010.

DOW-CHEMICAL. Disponível em: <https://br.dow.com/pt-br>. Acesso em: 26 out. 2018.

GOES, T.; MARRA, R. 2009-2010 - Setor sucroenergético frente a crise mundial. EMBRAPA, 2009. Disponível em: <www.embrapa.br〉. Acesso em: 15 nov. 2017. 
GUIMARÃES, S. P. Capital nacional e capital estrangeiro. Estudos Avançados. São Paulo. V. 14, no 39, p. 143-160, 2000. https://doi.org/10.1590/S0103$\underline{40142000000200011}$

HAESBAERT, R. Dos múltiplos territórios à multiterritorialidade. Porto Alegre, Setembro de 2004. Disponível em: http://www6.ufrgs.br/petgea/Artigo/rh.pdf. Acesso em: 01 nov. 2019.

MACÊDO, F. S. A reestruturação do setor sucroenergético no Brasil: uma análise do período entre 2005 e 2011. 2011, 71 f. Dissertação (Escola de Economia de São Paulo)-FGV, São Paulo, 2011.

MEDEIROS, M, C. Estado, capital financeiro e agricultura no Brasil atual. In: Encontro Nacional de Pós-Graduação em Geografia. Anais..., Campinas, p. 6223-6232, 2015.

Ministério da Agricultura, Pecuária e Abastecimento - MAPA. Disponível em: <http://www.agricultura.gov.br/>. Acesso em: 2018/2019.

NOVACANA. Disponível em: <https://www.novacana.com/>. Acesso em: 2018/2019.

OLIVEIRA, A. U. A mundialização da agricultura brasileira. In: Coloquio de Geocrítica. Anais..., Bogotá, 2012.

OLIVEIRA, A. U. A mundialização da agricultura brasileira. São Paulo: Iãnde Editorial, 2016.

PEREIRA, M. F. V. Os agentes do agronegócio e o uso do território no Triângulo Mineiro/Alto Paranaíba: da moderna agricultura de grãos à expansão recente da canade-açúcar. Revista do Departamento de Geografia - USP, v. 23, p. 83-104, 2012. https://doi.org/10.7154/RDG.2012.0023.0004

PINHEIRO, J, C. Análise da dinâmica das áreas ocupadas pela cultura canavieira no Brasil entre 1990 e 2013: uma contribuição ao estudo do circuito espacial produtivo do setor sucroenergético. 2015, 173 f. Dissertação (Mestrado em Análise Ambiental e Dinâmica Territorial) - Instituto de Geociências - Unicamp, Campinas, 2015.

PITTA, F. T.; XAVIER, C. V.; NAVARRO, C.; MENDONÇA, M. L. Empresas transnacionais e produção de agrocombustíveis no Brasil. Rede Social de Justiça e Direitos Humanos, Outras Expressões: São Paulo, p. 37-44, 2014.

SANTOS, H. F. Competitividade regional do setor sucroenergético na mesorregião Triângulo Mineiro/Alto Paranaíba: agricultura científica globalizada e implicações socioambientais no município de Uberaba - MG. 2017. 286 f. Dissertação (Mestrado em Geografia) - Instituto de Geociências, Unicamp/Campinas, 2017.

SAUER, S. Corrida mundial por terras e direitos territoriais no Brasil. Revista Agriculturas. Rio de Janeiro, v. 8, nº 4, p. 15-19, 2011. 
SOUZA, J. G. A produção brasileira de etanol e seus efeitos sobre o valor da terra, sobre a concentração fundiária e sobre a homogeneização da paisagem. Diversitates UFF, v. 5 n. 1, p. 29-58, 2013.

SINDICATO da Indústria de Fabricação do Álcool no Estado de Minas Gerais SIAMIG. Disponível em: <http://www.siamig.org.br/>. Acesso em 2018/2019.

SIQUEIRA, P, H, L; CASTRO JUNIOR, L, G. Fusões e aquisições das unidades produtivas e da Agroindústria de Cana-de-Açúcar no Brasil e nas Distribuidoras de Álcool Hidratado Etílico. RESR. Piracicaba, 2010, p. 709-735.

https://doi.org/10.1590/S0103-20032010000400009

SPOSITO, E. S.; SANTOS, L. B. O capitalismo industrial e as multinacionais brasileiras. São Paulo: Outras Expressões, 2012, 296 p.

STACCIARINI, J. H. S., O setor sucroenergético no Triângulo Mineiro (MG): crescimento econômico e manutenção das desigualdades sociais em municípios especializados. 2019. 135 f. Dissertação (Mestrado em Geografia e Gestão do Território) - Instituto de Geografia, UFU, Uberlândia, 2019.

TERRAS em Minas Gerais encareceram até 42\% em 2013. RuralBR. 29 dez. 2013. Disponível em <www.ruralbr.com.br>. Acesso em 18 jan. 2019.

THOMAZ JUNIOR, A. Dinâmica territorial do agrohidronegócio e os desdobramentos para o trabalho. Revista Oraka: Geografia em debate. João Pessoa, v. 6, nº 1, p. 7-31, 2012.

UNIÃO da Indústria de cana-de-açúcar - UNICA. Disponível em: <www.unica.com.br>. Acesso em 2018/2019.

UNIÃO dos Produtores de Bioenergia - UDOP. Disponível em: <www.udop.com.br>. Acesso em 2018/2019.

VENCOVSKY, V. P. Setor sucroenergético: a emergência de um novo período. In: BENRARDES, J. A.; SILVA, C. A.; ARRUZZO, R. C. (Org.). Espaço e energia: mudanças no paradigma sucroenergético, Rio de Janeiro. Editora Lamparina, 2013. 224 p. p. 51-62.

XAVIER, C. V.; PITTA, F. T.; MENDONÇA, M. L. A crise econômica mundial e a dívida do agronegócio canavieiro. In: MERLINO, T.; MENDONÇA, M. L. (Org.).

Relatório da Rede Social de Justiça e Direitos Humanos. São Paulo, 2012.

WILKINSON, J. O setor sucroalcooleiro brasileiro na atual conjuntura nacional e internacional. Rio de Janeiro: ActionAid Brasil, 2015.

Recebido em 27/12/2019.

Aceito para publicação em 11/05/2020. 